\title{
Silat Foundations in the Creation of the Minang Dance 'Balega Di Tanah Manang' (Rotation Around the Land of Conquest)
}

\author{
Susas Rita Loravianti* \\ Dance Department, Faculty of Performing Arts, Indonesian Institute of the Arts Padangpanjang, \\ WestSumatra, Indonesia \\ M. Halim \\ Karawitan Department, Faculty of Performing Arts, Indonesian Institute of the Arts Padangpanjang, \\ West Sumatra, Indonesia \\ Wendy HS. \\ Theatre Department, Faculty of Performing Arts, Indonesian Institute of the Arts Padangpanjang, \\ WestSumatra, Indonesia \\ Emri \\ Dance Department, Faculty of Performing Arts, Indonesian Institute of the Arts Padangpanjang, \\ WestSumatra, Indonesia
}

This research was funded by the Directorate for Research and Community Service, Directorate General forResearch and Development, Ministry of Research, Technology, and Higher Education.

\begin{abstract}
'Balega in Tanah Manang,' meaning the "Rotation Around the Land of Conquest" in the Minang language of West Sumatra, is a dance piece that was created through the combined use of pancak movements (based in the Minangkabau martial art form pencaksilat) and dance movements and new techniques beyond pancak. This phenomena in Minangkabau dance is possible because pancak, typically the playful performance by men in both local and regional spaces, forms the principle foundation for the dance.Through this collaborative effort, pancakis transformed to become a dance performing art form that isengages with women as its dancers, choreographers, and participants of dance activities.Silat is the oldest martial arts form in the Minangkabau region of Indonesia's West Sumatra. Each region within the Minangkabau area has its own silat movements, with fundamental differences. In general, there are two forms of traditional silat,kudo-kudo and pitunggua, that are very different. Silat is less associated withkudo-kudo; pitunggua is better known.Pitunggua shows a loose foot position, one in which you can easily take a step forward. A silat practitioner must know garak garik, raso pareso, mailak, gelek, pandang, kutiko. Garak means large movements. Garik means small movements. Lantakin motion means to avoid using gelek. The 'Balega di Tanah Manang' dance piece (Rotation Around The Land of Conquest) begins with the Minang philosophy of alam takambang jadi guru. Nature serves as the teachings of and a viewpoint on life that guide human interactions, actions, and behavior. In Minangkabau culture too, they make all forms of adverbs based on life that exists in the universe. This is then used to make customary rules, laws, and provisions. They apply all of this in their daily lives. That is what is called Minangkabau teachings.
\end{abstract}

Keywords: silat, dance, Minangkabau, andphilosophy

Publication date: December $31^{\text {st }} 2019$

DOI: $10.7176 /$ ADS/79-01

Publication date: December $31^{\text {st }} 2019$

\section{Introduction}

The development of performing arts over the past two decades has shown an expansion of understanding about performance itself. This subject can be explored further in the discourse that is unraveled in the book Performance Studies: An Introduction by Richard Schechner (2002). Visual and invisible comprehesion is achieved when watching a performing arts piece, and ultimately there is a 'blurring' or 'melting' of the various boundaries across art disciplines, such as the boundary between theater, dance, and music arts. In many cases within performances, especially over the past two decades, the phenomenon that takes place makes it difficult for us to classify what we see according to the conventions across theater, dance, and music standards. Schechner (2002: 11) offers an understanding ofwhat we see as performance, as a deliberate attempt to perform in front of certain publics. The public that Schechner suggests can be understood asthe relation of one individualto someone else, including the form of a relationship between two people who are friends with each other.

On the basis of understanding deliberate performance of the self, as described by Richard Schechner (2002), performance will be broadly understood asan agreement of two (or more) friends to meet at a given place, discussion event, meeting, or deliberation of an organization, a professional boxing event, football match, religious 
ritual, birthday party, wedding, wedding reception, circumcision event, educational event in schools and colleges, as well as events such as demonstrations, official institutional inauguration, and so forth. Indirectly, Schechner opened the valve for many daily events in the social sphere that are intended to showoneself to the public, all of which may be called performance.

Meanwhile, analytical scholarship exists that illustrates the development of the performing arts since the 1980s in various regions of West Sumatra, as well as across almost all regions of Indonesia. In general, referring to Wendy HS's report and working paperon the colossal performing artsstudent production in Padangpanjang 'Developing Educating Nature'(2014), it can be stated here that performance exists within a vacuum or suspended animation without production. The phrases vacuum or suspended animation without production certainly excludes productions that are technically classified as performing arts productions, but have became popular as 'opening ceremonial mass dances', both for ceremonial events in sports week, MTQ events, or commemorative national holidays. In this regard, if included in the productivity scale of performing arts in West Sumatra from the 1980s until now, it can be concluded that the level of performance is on average 1 time per year. This figure certainly shows the lack of production levels in the performing arts. Besides being constrained by this main factor and the higher cost of production, another obstacle also appears to be the development of creative ideas of production which cannot be separated from the 'mass dance' creative label.

Relating the description above to theperforming arts in a semiotics perspective,performance is seen as a certain form that is representing the evolutionary momentum that has been, is, or will be experienced by a particular social group. Regarding this, according to Victor Turner (1982) in his book entitled From Ritual to Theater: The Human Seriousness of Play, every staged event (performance) is an event created by the strong influence of social events (reality), and vice versa every social event (reality) is an event created by the influence of staged events (performances). Turner (1982) further states that the relationship between staged events (performances) and social events (reality) can be illustrated as a line forming the number eight, a shape that will never be broken. If one part of the number eight is considered a staged event (performance) and the other part of the line is considered a social event (reality), then the two curved lines will be connected to each other from two opposing directions. Each upper arch as a staged event (performance) that will lead to and form the lower curved line of the arch as a social event (reality). Vice versa, each upper arch as a social event (reality) will lead to and form the lower curved line of the arch as a staged event (performance). The two will be connected continuously without disruption and with mutual influence.

Starting with Victor Turner's opinionabove (1982), a relationship can be drawn connecting it with the results of Wendy HS's analysis (2014) of the lack of performing arts in West Sumatra and with Richard Schechner's (2002) revolutionaryunderstanding of performance. In general it can be concluded that the relationship across these three descriptions underlies the need for the production of 'Balega Di Tanah Manang' (Rotation Around The Land of Conquest). The basis of this production consists of three points, namely:One, projecting a picture of the crisis of performing arts productivity in West Sumatra; Two, projecting a picture of the conceptual motivational effort to understand this productivity crisis; and Three, projecting a picture of the technical foundation to overcome and end this crisis situation.

\subsection{Literature Review}

Previous researchers have discussed the process of performing arts creation in West Sumatra and in Indonesia generally, including basic ideas regarding the developmental stagnation of art forms and the low level of performing arts production. Thisissue can be traced through an analysis of thecreation of the dance piece titled'Garak Nagari Perempuan'by choreographer Susas Rita Loravianti - theperformanceof 'Alam Terkembang Mendidik' by director Wendy HS and choreographer Susas Rita Loravianti (2015), the drance drama 'Lini Lain Matrilini' by Wendy HS and choreographer Susas Rita Loravianti (2015), and the dance drama 'Rang Rumah'by Wendy HS and choreographer Susas Rita Loravianti (2016). In general, the process of creating these performing artspiecesbegan from the same awareness to engage the conventions of Minangkabau choreographic movements as a choice of artistic forms that have been commonly used in performing arts compositions, particularly modern/contemporary dance and dance dramas in West Sumatra which generally originate from Silek movements (traditional Minangkabau martial arts). Silek movements as the basis forchoreography is seen mostly through a transference from sports (martial arts) to performance without further consideration of the relationship between text and context. As a result, the Silek movements that become the basis for choreographyare almost always the same across various Minangkabau dances and dance dramas, both in modern and contemporary formats.

With an awareness of the ideas above, the process of creating 'Balega di Tanah Manang' (Rotation Around the Land of Conquest) was based upon efforts to develop artistic patterns through studies of Minangkabau dance movements based on Silek movements. This effortwas the result of analysis of creative processes of dance works and dance dramas by previous researchers, namely:

First, the creation of 'Garak Nagari Perempuan'by choreographer Susas Rita Loravianti and dramaturg Wendy HS (2014), which discusses the relationship between myths about women in tradition Minangkabau society 
and the current reality of women in Minangkabau communities. In general it can be stated that the relationship between the myths of women in Minangkabau custom, with the reality of women in Minangkabau society today, and its relationship to the creation of artistic events in the midst of public spaces, is connected by an awareness of the important power of words, the Silek movements, and the elements of public space as the artistic space of the show. These three elements form the basis of the dance drama'Garak Nagari Perempuan' (2014), which is typical of the Minangkabau people, as Wendy HS wrote in the Journal of Art Studies in Gadjah Mada University, Yogyakarta, about "Dramaturgy of Randai Folk Theater in Minangkabau" ( November 2014). This dramatic basis will later become one of the main thoughts and study materials for the creation of 'Balega Di Tanah Manang' (Rotation Around The Land of Conquest) later.

Second, the creation of the dance drama'Alam Terkembang Mendidik' by director Wendy HS and choreographer Susas Rita Loravianti (2015), which attempted to develop artistic movements of Minangkabau Silekinto an interactive and acrobatic artistic viewpoint. The idea of developing the artistic patterns of Minangkabau Silek movements in the process of creating 'Alam Terkembang Mendidik' (2015) was obtained through the development of the Minangkabau Silek movement artistic patterns in dance works and dance drama in West Sumatra during the last three decades, as reported by Wendy HS in 'Alam Terkembang Mendidi' for the Padangpanjang City Education Office (2015). Referring to this report, the development ofMinangkabauSilek artistic patterns in dance and dance drama over the past three decades is seen as tending to be in a state of artistic stagnation. The results of this reading are then used as a motive to overcome the stagnation of artistic patterns by making efforts to encourage the development of new forms of artistic movements in the Minangkabau Silek movement through dance and dance drama. For this reason, in the process of 'Alam Terkembang Mendidi' (2015), a development pattern that has sought the movement of Silek from its general nature which has a focus on the ability of personal performers (actors) only, becomes Silek movements that have a focus on the collective abilities of performers (actors). Furthermore, the technical movements ofSilekare then directed to become more attractiveinteractive and more acrobatic collectively among the performers or actors. However, the limited production costs mean that the dance drama 'Alam Terkembang Mendidi' (2015) was unable to present a full exploration and technical reinforcement for performers (actors) with a colossal number ( 250 performers / actors) and made it incapable of achieving maximum results. Based on this experience, researchers then tried to continue developing the artistic patterns of Minangkabau Silekmovements into an attractive, interactive and acrobatic artistic pattern as a dramatic pattern of 'Balega in Tanah Manang' (Rotation Around The Land of Conquest) later.

Third, the creation of the dance dramas 'Lini Lain Matrilini' (2015) and 'Rang Rumah' (2016) are creative processes that emerged from the results of research on the personal and social behavior of Minangkabau women in their daily lives, as converted into dramatic patterns of artistic events on the stage. The substance for this process lies in the effort to convert the daily reality of women's issues through the context of personal and social behavior in Minangkabau society today into a dance drama performance. 'Lini Lain Matrilini' (2015) and 'Rang Rumah' (2016) are used as the basis for artistic events in the performance of 'Balega Di Tanah Manang' (Rotation Around The Land of Conquest).Furthermore, these performances will provide the technical basis for artistic construction, especially regarding the formula for managing the performance space later. This formula for managing the intended performance space is related to the patterns and motifs used in determining semiotic elements through the choice of artistic material, both visible and invisible.

\subsection{Methodology}

The creation of Balega Di Tanah Manang (Rotation Around The Land of Conquest)\# 2 uses methods based upon 2 (two) basic performance constructions, namely:

1) Artistic Construction, in which the artistic layout of Balega Di Tanah Manang (Rotation Around The Land of Conquest) \# 2 is formed through the concept ofTotal Body Performance, a series of artistic works that approaches the performance of the body throughTapuak Galemboang artistic elements in traditional Minangkabau Randaias contemporary dance drama performance. In general, body performance within Randai originates from the body's behavior in the Silek tradition or the Minangkabau martial arts tradition. Therefore, theTotal Body Performanceconcept is a series of artistic works based on research of Silek movements in the Minangkabau community as a choice of body expression in its performance tradition. Furthermore, this artistic concept is data that has been formulated to the artistic development of dance and dance drama, both on a local scale in West Sumatra (especially related to dance and dance drama emerging from Minangkabau Silek movements), as well as on national and international scales. All data on the development of dance and dance drama will be parsed out according to differences in the artistic use of Minangkabau Silekmovements that occur, such as the stylization / styling ofSilekmovements related to tempo, leveling, dynamics, volume of motion and so on, when it is converted to the stage as part of a dance performance or dance drama. The locations for this data collectionwill be at various performing arts centers throughout West Sumatra and elsewhere in Indonesia in general. West Sumatra will be represented by the performing arts documentation center at SMKI Padang, TamanBudayaPropinsiSumatera Baratin Padang, UniversitasNegeriPadang andUniversitasAndalasinPadang,InsitutSeni Indonesia-Padangpanjang 
inPadangpanjang,as well as several arts communities and the Regency / City Arts Council in Bukittinggi, Payakumbuh, and Batusangkar. All data collected, both thematic and artistic, will be discussed with all personnel supporting the creation of the Balega Di Tanah Manang (Rotation Around the Land of Conquest) \# 3 work.

2)Thematic Construction, to support efforts to discuss the creation of Balega Di Tanah Manang (Rotation Around the Land of Conquest) \# 2, namely themes of Minangkabau women, Minangkabau traditional matrilineal beliefs and their reality in the Minangkabau community in West Sumatra today. This data collection beginswith the history of Minangkabau adat regarding women, emotional memories and daily experiences about the whereabouts of women and their position towards men, to studies of Minangkabau women and their matrilineal customs, both through print and online media. This research will take placein the Minangkabau cultural area or limited to the administrative area of West Sumatra province represented by the Luhak Nan Tigo region, namely the Tanah Datar regency (Pariangan nagari, Tabek nagari, and Simabua nagari), Agam district (Lasi nagari and Pua Sungai nagari areas). ), and the Limapuluh Kota and Rantau Darek regencies represented by Solok and Solok Selatan districts.

\subsection{Discussion}

Minangkabau society, as is generally well known, is one of the only matrilineal socio-cultural groups in the world, one that adheres to bloodlines determined by maternal/female bloodlines. Through this matrilineal system, various socio-cultural Minang traditions were created that are unique and interesting, especially related to their feminine values. This can be seen from the existence, role and function of women according to the beliefs of the sociocultural philosophy and behavior of Minangkabau people, to aspects of various choices in daily life or work practices of each individual Minang woman. What can be underlined here are two values of Minangkabau womanhood, namely: aspects of Minangkabau philosophical beliefs (ideological / social behavior of Minangkabau women); and aspects of daily life practices (the reality / daily behavior of Minangkabau women), which isless known by the wider community.

According to Raudha Thaib's (2010: 2-3) paper on the ideal role and function of Minangkabau women, it seems that a shift has emerged in the values of womanhood in Minangkabau society. This shift in the values of womanhood is seen through a comparison ofthe conceptual aspects of ideology and the factual aspects of reality in current Minangkabau society. This socio-cultural shift related to Minangkabau women can be viewed as one part of the phenomenon of socio-cultural development in Minangkabau society. Questions regarding the potential for socio-cultural development, specifically related to the issue of womanhood in Minangkabau community, are as follows:

First, why did this shift in the values of womanhood take place in Minangkabau society? What are the causes and motives for this shift? What is the relationship between the conceptual/ideological and factual/reality aspects of female values in current Minangkabau society?;

Second, how are the specific feminine values found in Minangkabau community actualized in "Balega di Tanah Manang" (Rotation Around The Land of Conquest), which has its own unique artistic appeal? How does 'Balega di Tanah Manang' (Rotation Around The Land of Conquest)become a medium for social awareness on the conditions of the Minangkabau community, especially regardingits feminine values? How does 'Balega Di Tanah Manang' (Rotation Around The Land of Conquest) serve as a marker of the diversity of the values of humanity and culture of Indonesia in the eyes of the world, especially related to the issue of womanhood?

\subsection{Structure of the Piece}

The structure of Balega Di Tanah Manang (Rotation Around The Land of Conquest)\# 2 is designed as a collage system. This means that the performance piececonsists of three parts or stage events, each of which is connected not linearly or chronologically. Rather, they are connected through the main narrative of the matrilineal system as a basis for establishing kinship relations and inheritance from the maternal lineage. This matter refers to the analysis of the artistic elements of Tapuak Galemboang in the Randai tradition.

Part one describes theimportant role of women in preparing for any Minangkabau cultural rituals, whether this is to celebrate birth, circumcision, marriage, Datuak inauguration, establishment of the Rumah Gadang, as well as rituals pertaining to other cultural activities. The role of the woman is inseparable from the needs and preparation of basic facilities (places, food, clothing and jewelery) for these rituals.

In terms of form, it begins with the reformulation of the Talempoang Pacik procession from its original form (meaning Talempoangis the source of sound) into a form of acapella, beatbox, or sound from the performer $\mathrm{him} /$ herself as the source of sound. This can be done by using a rhyme formation considering the choice of diction (words) and the sound of the word as a reflection of the Talempoang Pacik tradition which is connected to the thematic rituals in this section.

Through this Talempoang Pacik reformation process, all performers can explore the choice of sounds, rhythms and movements that are deemed appropriate to describe a ritual process in Minangkabau culture. That is, in this section, there is no longer any difference between musicians, dancers or actors. All of them are performers, 
all of whom produce sounds and movements at the same time from their bodies as collective behavior.

In the end, however, the expected result shows the different areas of female and male activities as a unity of their social territory (shared life activities). This can be achieved by addressing the form of unity, for example the existence of a kitchen and living room in a Rumah Gadang in Minangkabau culture. Women tend to be more dominant in the back area (kitchen), while men tend to be in the living room and yard.

The unity of movement and sound in this continuous Talempoang Pacik reformation will then become the main acting form which will shape events on stage. This stage event can be seen as the practice of enjoying a photo slide of various activities of Minangkabau women and various activities of Minangkabau men in a process of cultural ritual.

Part two describes the real work of women in Minangkabau culture. This matter will further explain the tangible manifestation of the matrilineal kinship and system of work adopted by the Minangkabu community in various stages of preparing for ritual activities. Why choose cultural rituals? Cultural rituals certainly cannot be separated from the identification of various ritual activities which are always carried out collectively and collegially within the matrilieal family order in Minangkabau society.

This section may begin with exploring one of the Minangkabau women's traditional activities in various forms of rituals, for example the Manjalang tradition, Manyilau Kandang or other similar tradition, to develop the elements of motion, sound and behavior. In this section, the goal is to show the work of women in establishing family relations in Minangkabau culture. This will be related to various symbols of the inheritance of collective property in Minangkabau culture. Related problems, for example, include housing, rice fields, fields and so forth.

Part threedescribes Minangkabau women's congress in the development of the Minangkabau cultural order, especially for the development of the current matrilineal cultural system. This section may begin by exploring the various markers of Minangkabau women's jewelry that have been developed into a common decoration today. For example, the change of bracelets into anklets can then be explored as contextual sound and behavior compositions.

In this section, various properties can also be used as decoration on a woman's body. In essence, this section tends to describe the behavior of Minangkabau women today who, consciously or unconsciously, begin to care less about conventional matrilineal principles. This seems, on the other hand, paradoxical, as Minangkabau female identity is borne with pride.

In general, variousSilek steps from different areas across the Minangkabau regionarethen formulated into the basic movement techniques that are typical of Minangkabau styles. The following will describe the basic technical movements that have been formulated from steps or stances in Minangkabau Silek, namely:

\section{Minangkabau Basic Techniques for Body Motion Strength}

This technique is derived from the basic body position in Minangkabau Silek called Kudo-kudo. Through this basic position, the source of body strength in Silekcan be traced and used as a basic technique of Minangkabau body strength for the creation of Balega di Tanah Manang (Rotation Around The Land of Conquest). This position is determined by the opening of the foot about one half of the shoulders' width. Body weight is placed on both legs equally.

\section{Minangkabau Basic Techniques for Body Motion Resistance}

This technique is derived from the body's respiratory system and the system of channeling energy through body movements engaged in theSilek tradition. The respiratory system in question is an attempt to do normal breathing while doing movement. Breathing is the main endurance factor while doing motion. For this reason, in this technique, breath is taken through the nose, held in the diaphragm, and exhaled back through the nose. This training is done by counting in with the breath, holding the breath in the diaphragm, and expelling it through the nose, in the same count. For example, if you take a breath in with a count of 7, then hold it in for a count of 7, and breath out also for a count of 7 . This breathing begins with the static kudo-kudo position and then continues by moving slowly and continuing with rapid movements. Furthermore, through respiratory awareness, awareness can be applied to the distribution of energy in the body.

\section{Minangkabau Basic Techniques of Body Movement Dynamics}

This technique is an effort to raise awareness of the level of motion (upper, medium and lower), speed of movement (slow, medium and fast), and rhythm of motion (a combination of levels and speed of motion). The training is carried out by initiating the position of kudo-kudo which is followed by stepping one foot forward, and followed by retreating. This exercise is done with the level of motion below, up to a medium level, and continued to the movement at the top level (high). Then proceed with movements that are done slowly, medium and fast.

\section{Minangkabau Basic Techniques for Both Motion Aesthetics}

This technique is an attempt to make a movement based on the elements of Gelek and Balabeh in traditional MinangkabauSilek. The Gelek element is an attempt to avoid the opponent's attack in Silek, while the Balabeh element is an effort to start an attack or a preparatory effort to defend against an opponent's attack. This was later transformed into a Minangkabau aesthetic technique for 'Balega Di Tanah Manang' (Rotation Around The Land of Conquest). The training is done by recognizing the ability of eye expression that adjusts to the dynamics of motion. Attention paid to the direction of eyes and facial expressions is one of the main elements that is closely 
related toSilek movements.

\subsection{ProposedThematics}

Balega Di Tanah Manang (Rotation Around The Land of Conquest) \#2 indicates the choice to create new performing arts works about Minangkabau women's issues, the belief in the Minangkabau traditional matrilineal system and its reality in the Minangkabau community in West Sumatra today. This data collection starts from the history of women in Minangkabau adat, emotional memories and daily experiences about the whereabouts of women and their position towards men, to studies of Minangkabau women and their matrilineal customs, both through print and online media. The research locations are in the Minangkabau cultural region or limited to the administrative area of West Sumatra province and represented by the Luhak Nan Tigo cultural region, namely the Tanah Datar regency area (Pariangan nagari, Tabek nagari, and Simabua nagari), Agam district (Lasi nagari and Pua Sungai nagari areas), and the Limapuluh Kota and Rantau Darek regencies represented by Solok and Solok Selatan districts.

\subsection{Total Body Performance}

The TotalBodyPerformancemethod is based on Minangkabau culture, and in this case the development of Tapuak Galemboangas an artistic element in the Minang Randai tradition. Indirectly, this work is an effort to actualize the distinctive Minangkabau movements into a composition using the Total Body Performance method as an alternative choice to artistic stage concepts. This issue relates to thematic concepts of creating stage events or performance texts, recruitment performers (consisting of dancers, musicians and actors), artistic devices (properties, handproperties, set of lights, lighting arrangements, make-up and costumes), as well as music compositions. Broadly speaking, it can be stated that in the third or final stage, the final touch engages with the Total Body Performance method as the concept of the body in contemporary performing arts, dramatic and artistic formulation of the body inMinangkabauSilek as an alternative to the identity of Indonesian-style show typical of West Sumatra.

Later at the third stage, 'Balega Di Tanah Manang' (Rotation Around The Land of Conquest)will enter the international arena. For this reason, this piece will try to be displayed at performing arts events in Europe. This issue aims to introduce an alternative form and knowledge of contemporary performing arts that is uniquely Indonesian, in this case represented by the distinctive styles of Minangkabau culture, Silek, Tapuak Galemboang and Randai.

\section{Conclusion}

The process of creating Balega Di Tanah Manang (Rotation Around The Land of Conquest) is an attempt to understand Minangkabau Silek traditions as the basis for creating movementin the performing arts. It can be further concluded that the process carried out is an effort to re-actualizeSilek as a form of local knowledgewithin the Minangkabau community. This is then transformed as the basis for the creation of performing arts. That is, Silek can be used as a formulation of new methods as a choice of artistic forms in the development of performing arts that can be studied globally and scientifically, as a concept in Ballet and Opera performances.

This process is carried out by calculated planning. However, this practice cannot avoidvarious obstacles, such as those related to the number of holidays such as the fasting month, Eid holidays, and end of school year holidays. Although it is not in full accordance with the planned scheme, this can be resolved by consolidating the duration of meetings in the previous planning. The risk is that the meeting process becomes denser and the meeting duration is longer and tiring.

\section{References}

Abdullah, Taufik., Adat and Islam: An Examinating of Conflict in Minangkabau, in Kahin, Goeorge Mc Turnan \& Anderson, Ben O.G. (ed.), Indonesia Volume 2, Southeast Asia Programe Publications, Cornel University, New york, 1966.

Barba, Eugenio dan Savarese, Nicola. A Dictionary Of Theatre Anthropology: The Secret Art of The Performer, Routledge, London, 1991.

, On Directing and Dramaturgy: Burning the House, Routledge, New York, 2010.

Batuah, Ahmad Dt. dan Madjoindo, A. Dt. Tambo Minangkabau, Dinas Penerbitan Balai Pustaka, Djakarta, 1956. Dahana, Radhar Panca. Homo Theatricus dan Sejumlah Esai, Penerbit Yayasan IndonesiaTera, Magelang, 2001.

Edi Sedyawati \& Sapardi Djoko Damono (eds.), Seni Dalam Masyarakat Indonesia: Bunga Rampai, PT. Gramedia, Jakarta, 1983

, Pertumbuhan Seni Pertunjukan, Penerbit Sinar Harapan, Jakarta, 1981.

Hadi, Wisran. Sejarah Perkembangan Surau di Minangkabau, Makalah pada Program Pelatihan Gerakan Kembali Ke Surau, Biro Pemberdayaan Sospora, Sekretaris Daerah Propinsi Sumatera Barat, Pangeran City Hotel, Padang, 15-17 Juli 2007.

Hadler, Jeffrey., Sengketa Tiada Putus: Matriakat, Reformis Agama, dan Kolonialisme di Minangkabau, terjemahan Samsudin Berlian, Penerbit Freedom Institute, Jakarta, 2010. 
Harymawan, Dramaturgi, Remaja Rosdakarya, Bandung, 1993.

Kernodle, George R. Invitation to the Theatre, Horcourt, Brace \& Word, Inc., New York/Chicago/San Francisco/Atlanta, USA, 1967.

Lembaga Kerapatan Adat Alam Minangkabau (LKAAM) Sumatera Barat (ed.), Pengetahuan Adat Minangkabau, Kumpulan Makalah Pembekalan Pengetahuan Adat Minangkabau oleh LKAAM Sumatera Barat, Padang, 8 Agustus 2000.

Lichte, Erika Fischer. The Semiotics of Theatre, translate Jeremy Gaines \& Doris L. Jones, Indiana University Press, Bloomington and Indianapolis, 1992.

Luckhurst, Mary. Dramatugy: A Revolution In Theatre, Cambrigde University Press, New York, 2005.

M.P.S.S, Pudentia. (ed.). Metodologi Kajian Tradisi Lisan, Yayasan Obor Indonesia, Jakarta, 1998.

Malna, Afrizal. Perjalanan Teater Kedua: Antologi Tubuh dan Kata, iCAN, Yogyakarta, 2010.

Naim, Muchtar. Merantau: Pola Migrasi Suku Minangkabau, Gadjah Mada University Press, Yogyakarta, 1984.

Navis, A.A. Alam Terkembang Jadi Guru: Adat dan Kebudayaan Minangkabau, Grafiti Press, Jakarta, 1984.

Pauka, Kirstin. Conflict and Combat in Perfeormance: An Analysis of The Randai Folk Theatre of Minangkabau in West Sumatra, Disertasi program doktoral, University of Hawaii, Desember 1995.

Pramayoza, Dede. Sandiwara Kampuang di Sumatera Barat: Suatu Tinjauan Dramaturgi Atas Drama Poskolonial, Tesis pada Program Studi Pengkajian Seni Pertunjukan dan Seni Rupa, Sekolah Pascasarjana, Universitas Gadjah Mada, Yogyakarta, 2012.

Schechner, Richard. Performance Studies: An Introduction, Routledge, New York, 2002.

Simatupang, Lono. Pergelaran: Sebuah Mozaik Penelitian Seni-Budaya, Jalasutra, Yogyakarta, 2013.

Turner, Victor. From Ritual to Theatre: The Human Seriousness of Play, Performing Arts Journal Publication, New York, 1982. 